\title{
Credit Rationing and Mature French SMEs: A Disequilibrium Modela
}

\author{
Philippe Adair ${ }^{\mathrm{b}} \quad$ Mohamed AdAsKouc
}

Received: 08.11.2019; Revised: 10.03.2020; Accepted: 15.03.2020

\begin{abstract}
A conventional assumption that deserves testing is that small and medium-sized enterprises (SMEs) are most affected by credit crunch. In this respect, a disequilibrium model is designed to analyse the determinants of credit rationing upon a balanced panel of 2,370 mature French SMEs over the period 2002-2010. According to the estimates of simultaneous equations, the desired demand for bank credit is determined by exogenous factors from the supply-side. The credit supply-side validates best trade-off theory, whereas the credit demand-side validates best pecking order theory. The average share of rationed SMEs is seven per cent of the sample, suggesting that access to bank loans is not a major issue for mature French SMEs.
\end{abstract}

JEL codes: D53, G21, G23

Keywords: Balanced panel, Capital structure, Credit rationing, Disequilibrium model, French SMEs

\section{Introduction}

Small and medium-sized enterprises (SMEs) are the overwhelming category of companies worldwide. They contribute to both value-added and employment; they are also prone to large turnover as time goes by. SMEs must dispose of the financial resources necessary to keep their business going. As for external financing, SMEs depend on banks, especially for short-term loans, and the financial market does not offer an alternative solution. Banks often consider that the business projects of SMEs are riskier than those of larger companies. SMEs report discrimination in terms of access to finance and the risk assessment by banks that impose higher premium, increasing thereof the cost of credit.

The objective of banks is to contract with a borrower who can meet his commitments and whose probability of default is very low. This objective hardly coincides with the financial specificities of SMEs that are often considered to be riskier. In most SMEs, the entrepreneur concentrates ownership and direction of control in his/her own hands and imposes his/her choice of allocation of funds. SMEs often lack resources (staff, finance and time); their economic environment is characterised by uncertainty; personal relationships are more frequent; their inability to provide reliable and accurate market information is one

${ }^{a}$ We are grateful to two anonymous referees whose comments did help in improving this article. The usual disclaimer applies.

b Corresponding author. ERUDITE Research Unit, Faculty of Economics and Management, University Paris-Est Créteil, Créteil, France. e-mail: adair@u-pec.fr. (D) https://orcid.org/0000-0002-6474-2420

c Faculty of Law, Economics and Social Sciences, University Ibn Zohr, Agadir, Morocco. e-mail: m.adaskou@uiz.ac.ma (D) https://orcid.org/0000-0003-4426-9346 
of the major difficulties (Berger \& Udell, 1998). SMEs that are denied access to credit face rationing, which hinders their development and survival (Beck \& Demirgüç-Kunt, 2006). The exposure of SMEs to credit rationing is explained by both the ex-ante and ex-post asymmetry of information surrounding the loan agreement.

It is crucial to gauge the resilience of SMEs when they are facing a major downturn, such as the 2008 global recession. To what extent do they resist credit rationing? Is it due to characteristics such as age or maturity, ownership, size and the structure of their capital?

Indeed, the extent of credit rationing is a controversial issue. Kremp \& Sevestre (2013) estimates that less than 9 per cent of French SMEs were rationed during the 2000s, whereas Alexandre \& Buisson-Stéphan (2014) estimates that credit rationing affected 45.3 per cent of French SMEs. Here, age or maturity, ownership and size are worth considering: Kremp \& Sevestre (2013) uses a larger sample of independent SMEs including both mature and young companies, whereas Alexandre \& Buisson-Stéphan (2014) focuses upon young SMEs. Strangely enough, Kremp \& Sevestre (2013) finds that size variables exert a negative impact upon granting bank credit to SMEs, but they do not observe that older companies have more equity and use less bank debt as predicted by pecking order theory.

The measurement of credit rationing is a complicated exercise because both credit supply and demand are not directly observable. Various approaches addressing the existence of such a phenomenon have used opinion surveys or proxy variables, which raise problems that the modelling and estimation techniques of disequilibrium models seem to have overcome. The purpose of this article is to estimate a disequilibrium model (Maddala \& Nelson, 1974) in order to document the main determinants of credit rationing for a sample of 2,370 French SMEs selected in the DIANE database over nine years (2002-2010), to identify financially constrained enterprises and to calculate their proportion.

This article is structured as follows. Section 2 presents the theory of credit rationing applied to SMEs. Section 3 is dedicated to specify econometric methodology and empirical measurements of credit rationing, the disequilibrium model and the related assumptions. Section 4 presents the sample and descriptive statistics. Section 5 provides estimation outcomes as for credit both on the supply side and on the demand side. Section 6 calculates the proportion of firms rationed on the credit market. Section 7 recapitulates and discusses the main findings.

\section{Credit rationing theory and SMEs}

Credit rationing theory (Stiglitz \& Weiss, 1981) is built upon the assumption of nonobservability of the borrowers and the existence of information asymmetries. Credit rationing is an equilibrium wherein some borrowers get credit, whereas a priori identical other borrowers are denied credit, although they may be willing to pay a higher interest rate. This theory includes adverse selection according to which the higher the expected returns of an investment project, the higher the risk. High lending rates can attract reckless borrowers driving to the occurrence of moral hazard and have a negative impact on the expected receipts of lenders (Adair \& Adaskou, 2011). The setting of a credit cost such as supply and demand are in balance does not design a rational behaviour on the part of banks (Levratto, 1992), which are risk-averse thereby rationing loans rather than raising the required interest rate or collateral (Cieply, 1997). Credit rationing theory has been challenged as a special case by Su \& Zhang (2017), who does not, however, deny its existence. 
Stiglitz \& Weiss (1981) assumes that credit rationing also exists when several groups of borrowers are observable by the lender. Hence, companies applying for risky projects will be discriminated. This case illustrates the situation of SMEs on the credit market to the extent that they are riskier than larger firms (Psillaki, 1995). Yan (1997) points out that the risk of credit rationing is an increasing function of the probability of bankruptcy. Given the importance of SME defaults, credit rationing is a significant issue for these companies.

In order to encourage companies to comply with timely payback, banks have several ways to reduce the consequences of information asymmetry. They offer revealing contracts that aim to gauge the degree of risk of the potential borrower over time; such contracts consist in various combinations of the required interest rate and collateral (Besanko \& Thakor, 1987; Deshon \& Freixas, 1987). They also aim to build a customer relationship over time that improves the assessment methods of banks facilitating the provision of lower-cost credit (Haubrich, 1989; Diamond, 1989).

\section{Econometric methodology}

\subsection{Empirical measures of credit rationing}

The various approaches testing the existence of rationing in the credit market are based either on the results of opinion surveys as well as on the use of proxy variables or crosssectional data regarding the financial sensitivity of actual behaviour of companies. Among the studies based on the survey technique, that of Cieply (1997) examines the opinions and behaviours of a sample of 40 account managers facing asymmetric information: their behaviours comply with the predictions of credit rationing theory, and the existence of a customer relationship allows the bank to protect itself against moral hazard and opportunism. While such surveys illustrate the existence of rationing, they provide no measure. Moreover, the results are questionable because the data contain biases.

Fazzari et al. (1988), Hoshi et al. (1991) and Harhoff \& Körting (1998) use surrogate variables and exogenous classification of firms: those more likely vs. less likely to be exposed to financial constraints, which poses two problems (Atanasova \& Wilson, 2004). First, some of the proxy variables are endogenous because they result from firm decisions (e.g., capital structure) and thus are not appropriate measures of credit rationing. Second, the classification is rigid, ignoring the mobility of firms from the group of constrained companies to that of the unconstrained ones and vice versa (Adair \& Fhima, 2013).

The development of econometric modelling and estimation techniques for disequilibrium markets help avoid the problems faced by the aforementioned approaches. The models of disequilibrium address the existence of credit rationing and the potential constraints of access to bank credit for companies, and measure the impact of their characteristics on these constraints (Kremp \& Sevestre, 2013).

Two papers apply the disequilibrium model to the credit rationing of SMEs in France over the 2000s. Kremp \& Sevestre (2013) analyses a sample of 64,581 independent SMEs, including microenterprises from the Central Bank database (FIBEN-Banque de France) over 2004-2010. They find that young SMEs are more rationed than mature SMEs and that rationing increased from 2007 to 2010. Alexandre \& Buisson-Stéphan (2014) studies the impact of the 2008 recession, in terms of credit rationing upon a sample of 3,957 SMEs over 2000-2008; microenterprises are excluded from the sample whose source is not mentioned. They find that the SMEs most exposed to credit rationing are younger, experience higher 
growth rate, generate cash flow and have fewer assets to provide as collateral.

\subsection{The disequilibrium model: demand and supply of bank credit}

The disequilibrium model of Maddala (1983) consists of three equations: the demand function equation (1), the supply function equation (2) and an equation that corresponds to the condition according to which the quantity observed results from the minimum quantity respectively offered and requested (3). The model is designed as follows:

$$
\begin{aligned}
L_{t}^{d} & =\beta_{1} X_{1 t}^{\prime}+u_{1 t} \\
L_{t}^{s} & =\beta_{2} X_{2 t}^{\prime}+u_{2 t} \\
L_{t} & =\min \left\{L_{t}^{d}, L_{t}^{s}\right\}
\end{aligned}
$$

$L_{t}^{d}$ and $L_{t}^{s}$ respectively denote the amount of bank credit requested during period $t$ and the amount of bank credit offered during period $t$, unobservable variables that must be determined and explained; $L_{t}$ stands for the observed amount of bank credit, which is the minimum between the amount of bank credit offered and the amount requested, $X_{1 t}^{\prime}$ and $X_{2 t}^{\prime}$ respectively denote the vector of independent exogenous variables that influence the credit demand and supply, $\beta_{1}$ and $\beta_{2}$ are their respective coefficients, and $u_{1 t}$ and $u_{2 t}$ are the error terms.

The estimation of a disequilibrium model is carried out in three steps (Maddala, 1983; Steijvers, 2008; Adair \& Fhima, 2013; Alexandre \& Buisson-Stéphan, 2014). The first step concerns the estimation of the coefficients of each explanatory variable of the supply and demand equations. The second step, based on the estimated coefficients, calculates the adjusted values of credit demand and supply for each firm in the sample; thus, unobservable values of credit demand and supply are identified. The final step determines the rationed companies for each year. A company that is partially or totally rationed is deemed to be such when the amount of credit requested is greater than the amount of credit offered by the bank: $L_{i t}^{d}>L_{i t}^{s}$. Hence, the share of rationed enterprises is measured by simply comparing the adjusted values of credit demand and supply.

\subsection{Variables and testable hypotheses regarding the bank credit supply}

Table 1 summarizes the variables and hypotheses regarding bank credit supply. The size of the firm $(S I Z E)$ is a synthetic indicator of the risk associated with the core business of the firm. According to trade-off theory (including agency theory, TOT thereafter) (Modigliani \& Miller, 1963), the risk of bankruptcy would be weaker for large firms than for small businesses due to the diversification of their investments; therefore, the size must be positively correlated with the supply of credit. SMEs that increase their wage bill can be viewed by lenders as successful companies that have growth opportunities and are less prone to bankruptcy risk. However, credit applications from companies with growth opportunities may be rejected by banks that view such demand as signalling a risky business. Our first hypothesis (H1) is stated as follows: supply of credit is a function of the size of the firm positive as for TOT vs. negative as for the theory of bankruptcy costs.

Age $(A G E)$ corresponds to the difference between the first year of observation and the date of establishment of the company: its historical record grows as time goes by. According to pecking-order theory (POT thereafter) (Myers \& Majluf, 1984) and assuming that the 
company's self-financing capacity increases with age, older firms should use less bank credit. Conversely, according to agency theory (Jensen \& Meckling, 1976), the relationship between the age of the firm and the supply of credit should be positive: older firms enjoy a better reputation and more robust experience, which is a positive signal on the quality of potential investments that can lessen agency costs (Adair \& Adaskou, 2011). Our second hypothesis (H1) is stated as follows: supply of credit is a function of the age of the firm, increasing as for agency theory vs. decreasing as for POT.

The credit risk $(R I S K)$ corresponds to the probability of default of the company that would not be able to face its commitments. This probability $(p)$ is obtained from the score $(S)^{1}$ by the following formula:

$$
p=\frac{1}{1+\exp S}
$$

We classify SMEs according to three types of Basel II credit risk:

if $p<20 \% \quad$ : the company is considered to be low or medium risk $(L M R)$;

if $20 \% \leq p<25 \%$ : the company is considered to be high risk $(H R)$;

if $p \geq 25 \% \quad$ : the company is considered to reach unsustainable risk $(U R)$

With respect to asymmetry of information, $L M R$ and $H R$ companies should be less indebted than $U R$ firms. Our third hypothesis $(H 3)$ is stated as follows: credit risk exerts a negative influence on the supply of credit, according to both TOT and POT.

The requirement for collateral $(C O L L)$ plays a major role in the credit relationship (López-Gracia \& Sogorb-Mira, 2008). The lenders use it to mitigate the default risk, and it is a self-selection device for borrowers. Such a requirement may deter executives from underinvesting and making discretionary deductions (Jensen \& Meckling, 1976; Myers, 1977). Corporate assets or the personal contributions of managers tame moral hazard (Voordeckers \& Steijvers, 2006); in case of default, sequestrated guarantees increase the losses of the company, which is therefore encouraged to choose less risky projects (Besanko \& Thakor, 1987; Berger \& Udell, 1990). Collateral reduces agency costs and drives creditors to grant long-term loans (Jensen \& Meckling, 1976). According to Titman \& Wessels (1988), companies with (tangible) assets that can stand as collateral are more indebted. In contrast, Stiglitz \& Weiss $(1981,1987)$ argue that the requirement of higher collateral can lead the borrower to undertake riskier projects in order to offset the opportunity cost of collateral sequestration. This requirement also crowds out agents who have a strong aversion to risk.

In turn, Bester $(1985,1987)$ challenge Stiglitz and Weiss's argument, arguing that the provision of assets as collateral can reveal the quality of the business. The risky borrower chooses a contract combining low collateral with a higher interest rate, whereas the riskaverse borrower prefers a contract requiring a larger amount of collateral and a lower interest rate. These revealing contracts can substitute for the expensive collection of information on companies (Adair \& Adaskou, 2015).

1 The score function is: $\mathrm{S}=0.3665+0.0388^{*} \mathrm{FA} 0.3801 * \mathrm{FIR}+0.0217 * \mathrm{CF}+0.0524 * \mathrm{P}+0.0809 * \mathrm{NI}$ 0.00495*PE. FA stands for financial autonomy, FIR for financial interest rate, CF for cash flow, $\mathrm{P}$ for performance, NI for net income and $\mathrm{PE}$ for personnel expenses. All variables are exposed as a percentage. $\mathrm{FA}=(\text { Equity } / \text { Total balance sheet })^{*} 100 . \mathrm{FIR}=(\text { Interest } / \text { net turnover })^{*} 100 . \mathrm{CF}=($ Cash flow before distribution / Net sales + Operating subsidies $) * 100 . \mathrm{P}=($ Current result before tax $/$ Net sales + Operating subsidies $) * 100 . \mathrm{NI}=($ Net income $/$ Net equity $) * 100 . \mathrm{PE}=($ Personnel expenses + Employee profit-sharing / Value added)*100. See Altman (1968) for the default risk. 
Table 1: Hypotheses tested regarding the supply of bank credit

\begin{tabular}{|c|c|c|c|c|}
\hline Hypothesis & Variables & Calculus & Code & $L_{t}^{s}$ \\
\hline$H 1$ & $\begin{array}{l}\text { Risk of bankruptcy with respect to } \\
\text { the size of the firm }\end{array}$ & Ln(Total assets) & $S I Z E$ & + \\
\hline$H_{2}$ & $\begin{array}{l}\text { Reputation and experience of the } \\
\text { firm as a dynamic prospect }\end{array}$ & 2002 - date of establishment & $A G E$ & + or - \\
\hline H3 & Credit risk & Dummy variable & $R I S K$ & + or - \\
\hline $\mathrm{H}_{4}$ & $\begin{array}{l}\text { Required collateral with respect to } \\
\text { moral hazard }\end{array}$ & $\begin{array}{l}\text { (Property, plant and equipment }+ \\
\text { inventories) / Total assets } t-1\end{array}$ & $C O L L$ & + or - \\
\hline H5 & $\begin{array}{l}\text { Business risk related to the indus- } \\
\text { try }\end{array}$ & $\begin{array}{l}\text { Dummy variables (trade; construc- } \\
\text { tion and services; manufacturing is } \\
\text { the reference). }\end{array}$ & $I N D U S T$ & + or - \\
\hline$H 6$ & $\begin{array}{l}\text { Ownership (independent of third } \\
\text { party owned firm) }\end{array}$ & Dummy variable & $O W N$ & + or - \\
\hline
\end{tabular}

The collateral of a company can be calculated according to the share of property, plant and equipment and inventory in the balance sheet (Titman \& Wessels, 1988; Bourdieu \& Colin-Sédillot, 1993). Our fourth hypothesis (H4) is stated as follows: supply of credit increases vs. does not increase if companies are able to offer more assets as collateral.

The industry (INDUST) influences the supply of credit, in as much as each industry is characterised by specific operating modes and is also a synthetic indicator of the risk relating to the core business of the company (Psillaki et al., 2010). It may also reflect differences in the tax treatment or information of the creditors upon growth prospects of the companies (Bédué, 1997). This variable is measured by four dummy indicators (manufacturing, trade, construction and services) corresponding to the French Activity Nomenclature (NAF), level 60 (Adair \& Adaskou, 2011). Our fifth hypothesis (H5) is stated as follows: the industry wherein the company operates has a specific effect on the supply of credit.

A firm is considered to be either independent $(O W N)$ or owned by a third-party shareholder, according to the share owned by third parties (including other companies) in the capital of the firm. In this respect, two variables are included: dummy independent and dummy owned. Third-party owned companies may send a good signal to lenders who provide more credit than to their independent counterparts. Conversely, the control over capital structure and debt strategy are less constrained for independent firms than for owned enterprises. Our sixth hypothesis $(H 6)$ is stated as follows: Compared with third-party owned firms, credit supply to independent firms is larger (with respect to TOT) vs. weaker (POT).

\subsection{Variables and testable hypotheses regarding the demand for bank credit}

The variables and hypothesis regarding the demand for bank credit are listed in Table 2. The level of activity $(S A L E S)$ can influence the cash flow and drives the company to borrow (Atanasova \& Wilson, 2004; Steijvers, 2008). In accordance with POT, a company experiencing sustained growth confronts to a significant need for external financing; indebtedness seems to be the most satisfactory source of funding (Ziane, 2004). The combination of high growth and very limited access to financial markets drive SMEs to rely heavily on bank financing (Chittenden et al., 1996). Conversely, agency theory asserts that growth opportunities can lead to moral hazard: companies have to take more risk and struggle to convince their lenders to grant them credit. The level of business activity is measured by the ratio of sales to total assets in the previous year (Adair \& Adaskou, 2011). Our seventh hypothesis $\left(\mathrm{H}^{7}\right)$ is formulated as follows: demand for credit is a function of the level of ac- 
tivity of the company, which is positive according to POT vs. negative according to agency theory.

Gross Value Added ( $G V A$ ) can be constrained by the lack of internal resources, which drives the company to seek external financing (Atanasova \& Wilson, 2004; Steijvers, 2008; Alexandre \& Buisson-Stéphan, 2014). According to POT, the need for external financing is due to the fact that the company cannot finance its output level with its own self-financing capacity. This variable is approximated by the logarithm of value-added. Our eighth hypothesis $(H 8)$ is stated as follows: demand for credit is an increasing vs. decreasing function of the level of output of the firm, with respect to POT vs. agency theory.

Liquidity $(L I Q)$ is an indicator of the ability of the company to finance its own business cycle (Alexandre \& Buisson-Stéphan, 2014). This variable is approximated by the ratio of current short-term assets to current liabilities, within less than one year. This ratio gauges whether short-term resources cover liabilities and whether the company may avoid credit rationing. If the ratio is below 1 , the company may not be able to meet its commitments. If it is beyond 1, the company will be able to meet its commitments. A large ratio over 1, equivalent to positive working capital, may, however, prove to be too high, implying that the company does not make efficient use of its assets. Our ninth hypothesis (H9) is that credit demand is a decreasing function of liquidity.

Cash flow $(C A S H F)$ measures the internal resources available for financing the business thanks to the wealth generated by its activity, which is congruent with POT. The various studies that have tested this theory on French SMEs (Adair \& Adaskou, 2015) show that these companies first resort to internal financing and do look for external resources only when their self-financing capacity is exhausted. The available internal resources variable is approximated by the cash flow to total assets of the previous year. Our tenth hypothesis (H10) is stated as follows: demand for bank credit is a decreasing function of available cash flow with respect to POT.

Table 2: Hypotheses tested regarding the demand for bank credit

\begin{tabular}{lllll} 
Hypothesis & Variables & Calculus & Code & $L_{t}^{d}$ \\
\hline$H 7$ & Level of activity of the firm & Turnover / Total assets (t-1) & SALES & + \\
$H 8$ & Level of output of the firm & Ln(value added) & $G V A$ & + \\
$H 9$ & Liquidity & Current assets / Current liabilities & LIQ & - \\
$H 10$ & Available internal resources & Cash-flow / Total assets $t-1$ & $C A S H F$ & - \\
H11 & Trade credit & Trade credit to customers-trade credit & TCREDIT & + or - \\
& from suppliers / Total assets $t-1$ & & \\
H12 & Interest rate benchmark for & Euro interbank offered rate (average one & EURIBOR & - \\
& the bank & year) & & \\
\hline
\end{tabular}

Trade credit (TCREDIT) is an important source of short-term funding for SMEs. Unsatisfied credit demand can be offset by trade credit, which then represents a substitute for short-term bank debt (Atanasova \& Wilson, 2004). This credit is easily accessible even in a context of slow growth or recession when banks are reluctant to grant credit. Business relationships between companies and their suppliers are generally more harmonious than between firms and banks (Dietsch, 1998). According to TOT, indebtedness of a company towards its trading partners may be perceived by banks as a signal of good payback capacity, which may drive an increase in bank credit. This complementary relationship between trade credit and bank credit would, therefore, be positive. According to POT, trade credit is a significant and less risky source of short-term financing for SMEs: the substitution 
relationship between trade credit and bank credit would, therefore, be negative (Adair \& Adaskou, 2011). This variable is measured by the amount of trade payables net of trade receivables, compared to total assets of the previous year. Our eleventh hypothesis (H11) is stated as follows: the relationship between demand for bank credit and trade credit is positive vs. negative with respect to TOT vs. POT.

The Euro interbank offered rate $(E U R I B O R)$ at one year represents the benchmark interest rate for each year of the sample, upon which the bank fixes the cost of the debt for each company (Atanasova \& Wilson, 2004). Our twelfth hypothesis (H12) is as follows: demand for credit is a decreasing function of EURIBOR.

\section{Data and Descriptive Statistics}

\subsection{Sample}

The information comes from the DIANE database listing the accounts of French companies. The selection of SMEs is based on the available corporate accounts (updated 2010), according to eight criteria complying with the definition for SMEs from the European Commission (see Table A.1 in Appendix). These currently operating businesses are not listed on the financial market and have provided accounts for the years 2002 to 2010; the average workforce is below 250 employees, total assets are at most 43 million euros, and the turnover is below 50 million euros; they are selected according to their industry according to the French Activity Nomenclature (see Table A.2 in Appendix). We obtain a balanced panel of 2,370 mature SMEs and 21,330 observations over 2002-2010.

\subsection{Descriptive statistics}

Table 3 records 806 strictly independent SMEs accounting for one-third (34.01 per cent), whereas 1,564 third party owned SMEs represent about two-thirds (65.99 per cent) of the sample $^{2}$, among which directly owned SMEs (D Indicator) have the lion's share (55.53 per cent). Ownership is relevant: irrespective of the type of credit (a fixed rate, overdraft or

Table 3: Distribution of the sample according to ownership indicators

\begin{tabular}{lcc}
\hline Ownership Indicators & Frequency & Share (in \%) \\
\hline Total independent companies (A) & 806 & 34.01 \\
\hline Companies indirectly owned by third-party shareholder (B and C) & 248 & 10.36 \\
Companies directly owned by third-party shareholder (D) & 1,316 & 55.53 \\
All companies owned by third-party shareholder (B, C and D) & 1,564 & 65.99 \\
\hline All companies & 2,370 & 100 \\
\hline Source: DIANE database &
\end{tabular}

leasing), indebtedness of independent SMEs is more expensive than for third-party owned SMEs, given the average effective interest rate and charged fees.

Table 4 reports descriptive statistics of the variables for the sample of selected SMEs. We observe that the median company is almost 15 years old and owns 3.1 million euros in assets; its solvency ratio indicates that equity represents almost two-thirds of total debt; one-third of total assets are available for collateral. Eventually, its liquidity ratio (1.70)

${ }^{2}$ DIANE database includes ownership indicators addressing the concentration (or dilution) of ownership over the capital of a company vis-à-vis its shareholders. 
Table 4: Descriptive statistics

\begin{tabular}{lrr} 
Variable & Mean & Median \\
\hline Total assets (Million Euro) & $4,561.41$ & $3,116.05$ \\
Value added (Million Euro) & $2,108.74$ & $1,601.28$ \\
Age & 18.76 & 14.88 \\
Solvency ratio & 1.08 & 0.65 \\
Financial expense coverage ratio & 62.62 & 10.82 \\
Cash flow from operations & 0.1 & 0.09 \\
Collateral & 0.37 & 0.33 \\
Activity & 2.06 & 1.84 \\
Ln(value added) & 7.38 & 7.38 \\
Liquidity ratio & 2.17 & 1.7 \\
Trade credit & 0.06 & 0.06 \\
EURIBOR & 0.029 & 0.023 \\
\hline
\end{tabular}

Source: DIANE database

shows that it is able to finance its own business cycle, its short-term resources covering up its short-term expenses. There is no significant gap between the mean and the median as for some variables (Cash flow, Collateral, Activity, Liquidity ratio, Trade credit), although the gap proves wide enough as for both the Solvency ratio and Financial expense coverage ratio.

\section{Estimation results}

In Table 5 regarding credit supply, both the fixed-effects model (Whitin) and the randomeffects model $(F G L S)$ display rather low $R^{2}$. Whitin is the most relevant model because it expresses the share of the intra-individual variability of the dependent variable explained by those of the explanatory variables. With respect to the fixed-effects model and the random-effects model, the Fisher test and the Wald test are both significant at one per cent threshold. The Breusch-Pagan test shows that random effects are globally significant at the one per cent threshold.

The Hausman test regarding Whitin vs. FGLS is significant at the one per cent threshold, implying that the specific effects are correlated with the explanatory variables and that Whitin would be the preferable model. However, Whitin does not allow to estimate the impact of an invariant variable over time (here industry and the ownership of the company) because data are transformed into difference compared to the individual average. Between (inter-individual averages) could be used although the results are very close to those of OLS.

We eventually designed an instrumental variable model, including constant variables, which provides convergent and efficient estimates when the disturbances are correlated with some explanatory variables of the model (Adair \& Adaskou, 2015). The instruments used are as follows ${ }^{3}$. First, time-variant explanatory variables, twice exogenous, expressed both as individual averages and as deviations from the individual mean; second, time-invariant explanatory variables, twice exogenous; and finally, time-variant explanatory variables, simply exogenous, expressed as deviations from individual averages (Hausman \& Taylor, 1981). The explanatory variables that we assume to be endogenous and that vary over time are

3 'Simply exogenous' is expressed as follows: $E\left(\omega_{i t} \mid x_{i, t}^{k}\right)=0$ and $E\left(u_{i t} \mid x_{i, t}^{k}\right) \neq 0 ; k^{t h}$ regressor is correlated with the individual effect but not with the idiosyncratic term. 'Twice exogenous' is expressed as follows: $E\left(\omega_{i t} \mid x_{i, t}^{k}\right)=0$ and $E\left(u_{i t} \mid x_{i, t}^{k}\right)=0 ; k^{t h}$ regressor is correlated with neither of the two terms. 
Table 5: Estimation Results of Bank Credit Supply $\left(L_{t}^{s}\right)$

\begin{tabular}{|c|c|c|c|c|}
\hline Estimator & OLS & Within & $F G L S$ & Hausman-Taylor \\
\hline SIZE & $\begin{array}{c}0.004^{* * *} \\
(0.001)\end{array}$ & $\begin{array}{c}0.058^{* * *} \\
(0.002)\end{array}$ & $\begin{array}{c}0.035^{* * *} \\
(0.002)\end{array}$ & $\begin{array}{c}0.052^{* * *} \\
(0.002)\end{array}$ \\
\hline$A G E$ & $\begin{array}{c}-0.001^{* * *} \\
(0.000)\end{array}$ & $\begin{array}{c}-0.006^{* * *} \\
(0.000)\end{array}$ & $\begin{array}{c}-0.002^{* * *} \\
(0.000)\end{array}$ & $\begin{array}{c}-0.005^{* * *} \\
(0.000)\end{array}$ \\
\hline$R I S K$ Dummy $^{a} L M R$ & $\begin{array}{c}-0.036^{* * *} \\
(0.003)\end{array}$ & $\begin{array}{c}-0.035^{* * *} \\
(0.002)\end{array}$ & $\begin{array}{c}-0.034^{* * *} \\
(0.002)\end{array}$ & $\begin{array}{c}-0.036^{* * *} \\
(0.002)\end{array}$ \\
\hline RISK Dummy $H R$ & $\begin{array}{c}-0.034^{* * *} \\
(0.003)\end{array}$ & $\begin{array}{c}-0.021^{* * *} \\
(0.002)\end{array}$ & $\begin{array}{c}-0.021^{* * *} \\
(0.002)\end{array}$ & $\begin{array}{c}-0.021^{* * *} \\
(0.002)\end{array}$ \\
\hline Collateral $(C O L L)$ & $\begin{array}{c}0.285^{* * *} \\
(0.005)\end{array}$ & $\begin{array}{c}0.287^{* * *} \\
(0.007)\end{array}$ & $\begin{array}{c}0.289 * * * \\
(0.006)\end{array}$ & $\begin{array}{c}0.288^{* * *} * \\
(0.006)\end{array}$ \\
\hline Dummy $\operatorname{Trade}^{b}$ & $\begin{array}{c}0.012^{* * *} \\
(0.002)\end{array}$ & - & $\begin{array}{c}0.012^{* *} \\
(0.006)\end{array}$ & $\begin{array}{l}0.009^{*} \\
(0.006)\end{array}$ \\
\hline Dummy Construction ${ }^{b}$ & $\begin{array}{c}-0.009 * * * \\
(0.003)\end{array}$ & - & $\begin{array}{l}-0.004 \\
(0.007)\end{array}$ & $\begin{array}{c}-0.004^{*} \\
(0.008)\end{array}$ \\
\hline Dummy Services $^{b}$ & $\begin{array}{c}0.07^{* * *} * \\
(0.003)\end{array}$ & - & $\begin{array}{c}0.066 * * * \\
(0.007)\end{array}$ & $\begin{array}{c}0.055^{* * *} * \\
(0.009)\end{array}$ \\
\hline Dummy Ownership $(O W N)^{c}$ & $\begin{array}{c}0.004^{* *} \\
(0.002)\end{array}$ & - & $\begin{array}{c}0.009^{* *} \\
(0.005)\end{array}$ & $\begin{array}{l}0.008^{*} \\
(0.006)\end{array}$ \\
\hline Constant & $\begin{array}{c}0.059^{* * *} \\
(0.011)\end{array}$ & $\begin{array}{c}-0.263^{* * *} \\
(0.014) \\
\end{array}$ & $\begin{array}{c}-0.173^{* * *} \\
(0.014) \\
\end{array}$ & $\begin{array}{c}-0.233^{* * *} \\
(0.015) \\
\end{array}$ \\
\hline$R^{2}$ & 0.21 & 0.14 & 0.21 & \\
\hline Fisher Test & 629.61 & 640.71 & & \\
\hline Prob $>F$ & 0.000 & 0.000 & & \\
\hline Wald $\chi^{2}$ & & & $3,569.31$ & $3,674.99$ \\
\hline Prob $>\chi^{2}$ & & & 0.000 & 0.000 \\
\hline Breusch-Pagan Test & & & $38,769.42$ & \\
\hline Prob $>\chi^{2}$ & & & 0.000 & \\
\hline Hausman Test Within vs. FGLS & & & 788.29 & \\
\hline Prob Hausman & & & 0.000 & \\
\hline
\end{tabular}

credit risk and the age of the company. Exogenous variables varying over time are the size and collateral. Time-invariant exogenous variables are industry and ownership of the firm.

Regarding credit demand in Table $6, R^{2}$ also proves rather weak. With respect to both the fixed-effects and the random-effects model, the Fisher test and the Wald test are both significant at one per cent threshold. The Breusch-Pagan test shows that random-effects are globally significant at one per cent threshold ${ }^{4}$. The Hausman test proves non-significant at the 10 per cent threshold, which implies it does not allow us to differentiate the fixed-effects model (Whitin) vs. the random-effects model (FGLS). Hausman-Taylor does not apply to the demand-side. Hereafter, we comment on the results of the random-effects model $(F G L S)$.

\footnotetext{
${ }^{4}$ Actually, the Breusch-Pagan test is used to test the homoscedasticity of the error term of a linear regression model. This test is compared with the $\chi^{2}$ test and if the former proves higher than the latter, we reject the null hypothesis of the existence of heteroscedasticity. In our case, the Breusch-Pagan test proves higher than the $\chi^{2}$ test; the variance of errors being constant, there is no heteroscedasticity.
} 
Table 6: Estimation Results of Bank Credit Demand $\left(L_{t}^{d}\right)$

\begin{tabular}{|c|c|c|c|}
\hline Estimator & OLS & Within & FGLS \\
\hline Level of activity (SALES) & $\begin{array}{c}0.016^{* * *} \\
(0.001)\end{array}$ & $\begin{array}{c}0.052^{* * *} \\
(0.001)\end{array}$ & $\begin{array}{c}0.043^{* * *} \\
(0.001)\end{array}$ \\
\hline Output capacity ( $G V A)$ & $\begin{array}{c}-0.009^{* * *} \\
(0.001)\end{array}$ & $\begin{array}{c}0.003^{* * *} \\
(0.001)\end{array}$ & $\begin{array}{c}0.000 \\
(0.001)\end{array}$ \\
\hline Liquidity $(L I Q)$ & $\begin{array}{c}-0.003^{* * *} \\
(0.000)\end{array}$ & $\begin{array}{c}0.000 \\
(0.000)\end{array}$ & $\begin{array}{c}0.000 \\
(0.000)\end{array}$ \\
\hline Cash flow $(C A S H F)$ & $\begin{array}{c}-0.052^{* * *} \\
(0.013)\end{array}$ & $\begin{array}{c}-0.198^{* * *} \\
(0.01)\end{array}$ & $\begin{array}{c}-0.188^{* * *} \\
(0.01)\end{array}$ \\
\hline Trade credit (TCREDIT) & $\begin{array}{c}-0.122^{* * *} \\
(0.005)\end{array}$ & $\begin{array}{c}0.135^{* * *} \\
(0.006)\end{array}$ & $\begin{array}{c}0.079^{* * *} \\
(0.006)\end{array}$ \\
\hline Interest rate $(E U R I B O R)$ & $\begin{array}{c}0.000 \\
(0.001)\end{array}$ & $\begin{array}{c}-0.001^{* *} \\
(0.000)\end{array}$ & $\begin{array}{l}0.001^{*} \\
(0.000)\end{array}$ \\
\hline Constant & $\begin{array}{c}0.265^{* * *} \\
(0.01)\end{array}$ & $\begin{array}{c}0.237^{* * *} \\
(0.01)\end{array}$ & $\begin{array}{c}0.247^{* * *} \\
(0.01)\end{array}$ \\
\hline$R^{2}$ & 0.041 & 0.126 & 0.003 \\
\hline $\begin{array}{l}\text { Fisher Test } \\
\text { Prob }>\text { F }\end{array}$ & $\begin{array}{l}149.85 \\
(0.000)\end{array}$ & $\begin{array}{c}454.5 \\
(0.000)\end{array}$ & \\
\hline $\begin{array}{l}\text { Wald } \chi^{2} \\
\text { Prob }>\chi^{2}\end{array}$ & & & $\begin{array}{c}2,088.28 \\
(0.000)\end{array}$ \\
\hline Breusch-Pagan Test & & & $41,451.56$ \\
\hline Prob $>\chi^{2}$ & & & $(0.000)$ \\
\hline Hausman Test Within vs. FGLS & & & 809.17 \\
\hline Prob Hausman & & & 0.2 \\
\hline
\end{tabular}

\subsection{Results relating to the bank credit supply function}

The size variable (SIZE) exerts a positive and strongly significant effect on the decision to grant bank credit. When SIZE increases by one per cent, credit supply increases by 5.2 per cent. This result validates TOT and rejects the thesis according to which growth opportunities would be interpreted by banks as a signal of a risky business. SMEs extending their workforce would be considered by banks as businesses enjoying growth opportunities and less exposed to the risk of bankruptcy (Adair \& Adaskou, 2015). Hypothesis H1, a positive correlation of size with the supply of short-term and long-term credit is thus verified, in accordance with Steijvers (2008), although opposite to Alexandre \& BuissonStéphan (2014) who observes a negative relationship.

The age variable $(A G E)$ is negative and highly significant. This result invalidates the predictions of TOT and validates those POT according to which mature companies own more capital and resort less to bank credit. Hypothesis H2 according to which credit supply is a decreasing function of the age of the firm is thus verified. This result is in agreement with that of Steijvers (2008) concerning the determinants of the short-term credit supply, but it disagrees on the determinants of long-term credit supply (Steijvers, 2008) as well as with that of Alexandre \& Buisson-Stéphan (2014).

As for credit risk (RISK), the dummy variable $U R$ (unsustainable risk) standing as a reference, dummy variables $L M R$ (low or medium risk) and $H R$ (high risk) are negative and significant. Low, medium and high-risk businesses use less credit than those facing unsustainable risk. This result can be explained by self-selection, encouraging low-risk, medium and high-risk companies to avoid bank loans and use other financing sources such 
as trade credit and self-financing. Hypothesis $H 3$ is validated, credit risk has a negative influence on bank credit supply, which is compatible with both TOT and POT.

Collateral $(C O L L)$ exerts a positive and strongly significant effect on the decision to grant credit. Companies with property, plant and equipment and inventory in their balance sheet are more indebted than others. Hypothesis $H_{4}$ is verified, validating agency theory (TOT) in agreement with Steijvers (2008) and Alexandre \& Buisson-Stéphan (2014).

Industry (INDUST) influences the supply of bank credit; dummy variables are positive and significant. Banks supply more credit to firms operating in the services than to those in the trade industry. The construction industry is less indebted compared with the manufacturing industry. Hypothesis H5 is verified.

Ownership $(O W N)$, is significant and weakly positive, the dummy for companies owned by a third-party shareholder standing as a reference. Independent companies use bank credit more than owned companies. Hypothesis H6 is validated for TOT but not for POT.

\subsection{Results from the desired bank credit demand function}

The level of activity $(S A L E S)$ is highly positive and highly significant. A one per cent increase raises the demand for credit by around 5.2 per cent. This result confirms the predictions of $P O T$, according to which debt is the most appropriate external funding source for firms experiencing sustained growth (Ziane, 2004). Hypothesis $\mathrm{H}^{7}$ is therefore verified in agreement with Steijvers (2008) and Alexandre \& Buisson-Stéphan (2014).

The output capacity ( GVA) exerts a positive and strongly significant effect, whereby an increase raises the demand for credit. Companies unable to finance their business cycle with internal resources call on external financing. Hypothesis $H 8$ validates POT, according to Steijvers (2008), but opposes Alexandre \& Buisson-Stéphan (2014) who observes a negative relationship.

Liquidity $(L I Q)$ is positive but not significant. It is unclear whether short-term resources can cover liabilities and whether firms are in position to avoid credit rationing. Hypothesis H9 is, therefore, neither confirmed nor invalidated.

Cash flow $(C A S H F)$ is negative and highly significant: the demand for credit is a decreasing function of the internal resources of the company. This result is consistent with the predictions of POT. Hypothesis H10 is confirmed in accordance with Steijvers (2008), in contrast with Alexandre \& Buisson-Stéphan (2014) who observes a positive relationship. Trade credit (TCREDIT) is positive and strongly significant: an increase in trade credit raises the demand for bank credit. This result confirms TOT contending that trade credit complements bank credit. Hypothesis $H 11$ is therefore verified in agreement with Alexandre \& Buisson-Stéphan (2014).

The interest rate $(E U R I B O R)$ is weakly negative and significant: the demand for credit declines as the cost of debt increases. Hypothesis H12 of a negative correlation is thus confirmed in accordance with Alexandre \& Buisson-Stéphan (2014).

\section{Share of SMEs rationed on the credit market}

The share of SMEs financially constrained by banks is determined by comparing the adjusted credit supply and demand values of the models previously estimated. A company is rationed in year $t$ if the probability that the desired demand for credit exceeding the amount granted in the same year is beyond 0.5 (Gersovitz, 1980). This estimation method 
allows a switch between rationing and non-rationing regimes: a non-rationed enterprise in one year could be rationed another year (Atanasova \& Wilson, 2004; Adair \& Fhima, 2013). In Table 7, once the companies are classified for every year according to the rationed vs non-rationed regimes, we calculate the share of rationed SMEs over the total sample.

Table 7: Share of SMEs rationed on the credit market (2002-2010)

\begin{tabular}{ccccc}
\hline Year & Total & Rationed & Rationed (\%) & Variation rate (\%) \\
\hline 2002 & 2,370 & 235 & 9.92 & - \\
2003 & 2,370 & 211 & 8.90 & -10.21 \\
2004 & 2,370 & 177 & 7.47 & -16.11 \\
2005 & 2,370 & 159 & 6.71 & $-10,17$ \\
2006 & 2,370 & 155 & 6.54 & -2.52 \\
2007 & 2,370 & 153 & 6.46 & $-1,29$ \\
2008 & 2,370 & 133 & 5.61 & -13.07 \\
2009 & 2,370 & 114 & 4.81 & -14.29 \\
2010 & 2,370 & 107 & 4.51 & -6.14 \\
\hline $2002-2010$ & 21,330 & 1,444 & 6.77 & - \\
\hline
\end{tabular}

Over 2002-2010, the share of French SMEs applying for credit that are totally or partially rationed on the bank credit market is seven per cent on average. We observe that this share declines from one year to the next, including in 2009-2010 during which mature SMEs prove resilient. This result corresponds to that found by Kremp \& Sevestre (2013) who explains such low share by the implementation of credit mediation since the end of 2008, hence encouraging banks not to restrict their credit supply to SMEs. Only firms in bad financial position, i.e. for which banks would expect a significant default risk, have faced serious obstacles in accessing bank credit.

\section{Conclusion and discussion}

We studied the determinants of the credit rationing on a balanced panel of 2,370 French SMEs observed from 2002 to 2010. We measured the share of rationed SMEs over a period of 9 years, in particular, the impact of the 2008 recession. We used a simultaneous disequilibrium model that accounts for the existence of credit rationing and provides an endogenous classification of rationed and non-rationed enterprises.

Statistically significant estimates show that the desired demand for bank credit is determined by exogenous factors such as the collateral required by the banks and the interest rate. The trade-off theory/agency theory ( TOT) is best validated by variables attributed to credit supply (size, credit risk, collateral, industry and ownership). Conversely, the pecking-order theory $(P O T)$ is best validated by variables attributed to the demand for credit (level of activity, value, added and cash flow), whereas trade credit validates TOT and age validates POT.

It is worth mentioning our sample includes only mature French SMEs whether independent or not, whereas Kremp \& Sevestre (2013) uses a larger sample comprising only independent SMEs that are both mature and young. Size variable exerts a positive and strongly significant effect on the decision to grant bank credit to SMEs, whereas Kremp \& Sevestre (2013) finds a negative impact. We find that older companies have more equity and use less bank debt; furthermore, an increase in trade credit is a strong driver of demand for credit. Both these results oppose that of Kremp \& Sevestre (2013). As for other findings, our results are in agreement with that of Kremp \& Sevestre (2013): SMEs with larger 
disposable collateral are more indebted, demand for credit declines as the cost of debt rises and proves a decreasing function of the internal resources of the company.

The extent of credit rationing is a controversial issue. We estimate that seven per cent is the average share of rationed French SMEs in operation for a decade, a share pretty close to that of 7.30-8.80 per cent rationed SMEs found by Kremp \& Sevestre (2013), whereas Alexandre \& Buisson-Stéphan (2014) estimates there are 45.3 per cent rationed French SMEs, a figure that is over six times higher. This wide discrepancy over a similar time span may be due to a selection bias in the sample or the database itself, and to econometric modelling. Noteworthy is that age is a major criterion: our sample includes mature SMEs that survived at least since 2002; they prove less rationed and more resilient than young SMEs. This result is congruent with the result of Kremp \& Sevestre (2013) and corollary to that of Alexandre \& Buisson-Stéphan (2014) (2014) who observes rationing effects on young SMEs.

Although we do not ignore the small share of rationed mature SMEs, our recommendation is that authorities, such as the Central Bank and the Public Investment Bank for SMEs, should rather support younger SMEs, providing bail for both short and median-term loans in order to counteract credit rationing and promote long-term investment with shareholding in promising start-ups.

Our study faces limitations due to the nature of book data, the approximate measurement of some variables and the heterogeneity of SMEs. It is dependent on the analytical tools we used, notably the lack of estimation of fixed effects; data essential for better measurement of the risk are lacking in the database, such as the duration of credits or the number of contracted loans.

\section{References}

Adair, P., \& Adaskou, M. (2011). Théories Financières et Endettement des PME en France: Une Analyse en Panel [Financial Theories and the Leverage of SMEs in France: A Panel Data Analysis]. Revue internationale P.M.E, 24(3-4), 137-71. doi:10.7202/1013665ar

Adair, P., \& Adaskou, M. (2015). Trade-off-theory vs. Pecking-order-theory and the Determinants of Corporate Leverage: Evidence from a Panel Data Analysis Upon French SMEs (2002-2010). Cogent Economics \& Finance, 3(1), 1-12. doi: $10.1080 / 23322039.2015 .1006477$

Adair, P., \& Fhima, F. (2013). Le Financement des PME en Tunisie: Dépendance à l'égard des Banques et Rationnement du Crédit [Financing SMEs in Tunisia: Dependence towards Banks and Credit Rationing]. Revue internationale P.M.E., 36(3-4), 26-52. doi:10.7202/1024521ar

Alexandre, H., \& Buisson-Stéphan, H. (2014). L'impact de la Crise de 2008 Sur le Rationnement du Crédit des PME Françaises [The Impact of the 2008 Crisis upon Credit Rationing of French SMEs]. Revue internationale P.M.E., 27(2), 95-113. doi:10.7202/1026069ar 
Altman, E. (1968). Financial Ratios, Discriminant Analysis and the Prediction of Corporate Bankruptcy. Journal of Finance, 23(4), 589-609. doi:10.2307/2978933

Atanasova, C. V., \& Wilson, N. (2004). Disequilibrium in the UK Corporate Loan Market. Journal of Banking and Finance, 28(3), 595-614. doi:10.1016/S0378-4266(03)00037-2

Bédué, A. (1997). Choix Financiers des Entreprises et Comportement Bancaire," [The Financial Choices of Companies and Bank Behavior] (unpublished Ph.D. Dissertation). Université Paris 10, Nanterre, France.

Beck, T., \& Demirgüç-Kunt, A. (2006). Small and Medium-size Enterprises: Access to Finance as a Growth Constraint. Journal of Banking and Finance, 30(11), 2931-43. doi:10.1016/j.jbankfin.2006.05.009

Berger, A. N., \& Udell, G. F. (1990). Collateral, Loan Quality, and Bank Risk. Journal of Monetary Economics, 25(1), 21-42. doi:10.1016/0304-3932(90)90042-3

Berger, A. N., \& Udell, G. F. (1998). The Economics of Small Business Finance: The Roles of Private Equity and Debt Markets in the Financial Growth Cycle. Journal of Banking and Finance, 22(6-8), 613-73. doi:10.1016/S0378-4266(98)00038-7

Besanko, D., \& Thakor, A. V. (1987). Collateral and Rationing: Sorting Equilibria in Monopolistic and Competitive Market. International Economic Review, 28(3), 671-89. doi: $10.2307 / 2526573$

Bester, H. (1985). Screening vs. Rationing in Credit Markets with Imperfect Information. American Economic Review, 75(4), 850-55.

Bester, H. (1987). The Role of Collateral in Credit Markets with Imperfect Information. European Economic Review, 31(4), 887-99. doi:10.1016/0014-2921(87)90005-5

Bourdieu, J., \& Colin-Sédillot, B. (1993). Structure de Capital et Coûts d'Information: Le Cas des Entreprises Françaises à la Fin des Années Quatre-vingt [Capital Structure and Information Costs: The Case of French Companies in the Late Eighties]. Economie et Statistique, 268-269, 87-100. doi:10.3406/estat.1993.5812

Chittenden, F., Hall, G., \& Hutchinson, P. (1996). Small Firm Growth, Access to Capital Markets and Financial Structure: Review of Issues and an Empirical Investigation. Small Business Economics, 8, 59-67. doi:10.1007/BF00391976

Cieply, S. (1997). Spécificité Financière des PME et Nouvelles Théories du Financement: Une Application à un Échantillon d'Entreprises Françaises [The Financial Specificity of SMEs and New Financing Theories: An Application to a Sample of French Companies] (unpublished Ph.D. Dissertation). Université Lyon 2, Lyon, France.

Deshon, M., \& Freixas, M. (1987). Le Rôle de la Garantie Dans le Contrat de Prêt Bancaire [The Role of Collateral in the Bank Loan Contract]. Finance, 8(1), 7-32.

Diamond, D. W. (1989). Reputation Acquisition in Debt Markets. Journal of Political Economy, 97(4), 828-62. doi:10.1086/261630 
Dietsch, M. (1998). Atouts et Handicaps du Crédit Client Face au Crédit Bancaire [Strengths and Handicaps of Trade Credit vs. Bank Credit]. Revue d'Économie Financière, 46(2), 175-93. doi:10.3406/ecofi.1998.2655

Fazzari, S. M., Hubbard, R. G., \& Petersen, B. R. (1988). Financing Constraints and Corporate Investment. Brookings Papers on Economic Activity, 1988(1), 141-206. doi: $10.2307 / 2534426$

Gersovitz, M. (1980). On Classification Probabilities for the Disequilibrium Model. Journal of Econometrics, 14(2), 239-46. doi:10.1016/0304-4076(80)90093-7

Harhoff, D., \& Körting, T. (1998). Lending Relationships in Germany - Empirical Evidence from Survey Data. Journal of Banking and Finance, 22(10-11), 1317-53. doi:10.1016/S0378-4266(98)00061-2

Haubrich, J. (1989). Financial Intermediation, Delegated Monitoring and Long Term Relationships. Journal of Banking and Finance, 13(1), 9-20. doi:10.1016/03784266(89)90015-0

Hausman, J. A., \& Taylor, E. (1981). Panel Data and Unobservable Individual Effects. Econometrica, 49(6), 1377-98. doi:10.2307/1911406

Hoshi, T., Kashyap, A., \& Scharfstein, D. (1991). Corporate Structure, Liquidity, and Investment: Evidence from Japanese Industrial Groups. The Quarterly Journal of Economics, 106(1), 33-60. doi:10.2307/2937905

Jensen, M. C., \& Meckling, W. H. (1976). Theory of the Firm: Managerial Behavior, Agency Costs and Ownership Structure. Journal of Financial Economics, 3(4), 305-60. doi:10.1016/0304-405X(76)90026-X

Kremp, E., \& Sevestre, P. (2013). Did the Crisis Induce Credit Rationing for French SMEs? Journal of Banking and Finance, 37(10), 3757-72. doi:10.1016/j.jbankfin.2013.05.028

Levratto, N. (1992). Une Analyse du Marché du Crédit en Termes de Rationnement [An Analysis of the Credit Market in Terms of Rationing] (unpublished Ph.D. Dissertation). Université de Nice Sophia-Antipolis, Nice, France.

López-Gracia, J., \& Sogorb-Mira, F. (2008). Testing Trade-off and Pecking-order Theories Financing SMEs. Small Business Economics, 31, 117-36. doi:10.1007/s11187-007-90884

Maddala, G. S. (1983). Limited-Dependent and Qualitative Variables in Econometrics. Cambridge University Press.

Maddala, G. S., \& Nelson, F. D. (1974). Maximum Likelihood Methods for Models of Markets in Disequilibrium. Econometrica, 42(6), 1003-30. doi:10.2307/1914215

Modigliani, F., \& Miller, M. H. (1963). Corporate Income Taxes and the Cost of Capital: A Correction. American Economic Review, 53(3), 433-43. 
Myers, S. C. (1977). Determinants of Corporate Borrowing. Journal of Financial Economics, 5(2), 147-75. doi:10.1016/0304-405X(77)90015-0

Myers, S. C., \& Majluf, N. S. (1984). Corporate Financing and Investment Decisions When Firms Have Information that Investors Do Not Have. Journal of Financial Economics, 13(2), 187-221. doi:10.1016/0304-405X(84)90023-0

Psillaki, M. (1995). Rationnement du Crédit et PME: Une Tentative de Mise en Relation [An Attempt to Match Credit Rationing with SMEs]. Revue Internationale PME, 8(3-4), 67-90. doi:10.7202/1008359ar

Psillaki, M., Tsolas, I. E., \& Margaritis, D. (2010). Evaluation of Credit Risk Based on Firm Performance. European Journal of Operational Research, 201(3), 873-81. doi:10.1016/j.ejor.2009.03.032

Steijvers, T. (2008). Existence of Credit Rationing for SMEs in the Belgian Corporate Loan Market (Working Paper). Social Science Research Network (SSRN). doi:10.2139/ssrn.495162

Stiglitz, J. E., \& Weiss, A. (1981). Credit Rationing in Markets with Imperfect Information. American Economic Review, 71(3), 393-410.

Stiglitz, J. E., \& Weiss, A. (1987). Credit Rationing with Many Borrowers. American Economic Review, 77(1), 228-31.

Su, X., \& Zhang, L. (2017). A Reexamination of Credit Rationing in the Stiglitz and Weiss Model. Journal of Money, Credit and Banking, 49(5), 1059-72. doi:10.1111/jmcb.12406

Titman, S., \& Wessels, R. (1988). The Determinants of Capital Structure Choice. Journal of Finance, 43(1), 1-19. doi:10.1111/j.1540-6261.1988.tb02585.x

Voordeckers, W., \& Steijvers, T. (2006). Business Collateral and Personal Commitments in SME Lending. Journal of Banking and Finance, 30(11), 3067-86. doi:10.1016/j.jbankfin.2006.05.003

Yan, Y. (1997). Credit Rationing, Bankruptcy Cost and Optimal Debt Contract for Small Business (Working Paper No. 9702). Federal Reserve Bank of Cleveland.

Ziane, Y. (2004). Structure Financière, Relations Bancaires de Long Terme et Financement Interentreprises des PME Françaises." [Financial Structure, Long-term Banking Relationships and the Intercompany Financing of French SMEs) (unpublished Ph.D. Dissertation). Université Paris 10, Nanterre, France. 


\section{Appendix: Additional Tables}

Table A.1: Thresholds for SMEs

\begin{tabular}{lccc}
\hline Business category & Employees & Turnover, Mil. Euro & Total balance sheet, Mil. Euro \\
\hline Microenterprise & $0-9$ & 2 & 2 \\
Small business & $10-49$ & 10 & 10 \\
Medium-sized enterprise & $50-249$ & 50 & 43 \\
\hline Source: European Commission. Effective from the 1st of January 2005.
\end{tabular}

Table A.2: Classification of Industries

\begin{tabular}{lll} 
Number & Industry & Code \\
\hline 1 & Agriculture and Food Industry; Energy & $10-16,23,40-41$ \\
2 & Consumer Goods Industry & $17-19,35-37$ \\
3 & Automotive Industry & 34 \\
4 & Capital Goods Industry & $29-33$ \\
5 & Intermediate Goods Industry & $20-22,24-28$ \\
6 & Construction & 45 \\
7 & Trade & 50 and 52 \\
8 & Services (transportation, real estate, business & $60-62,63-64,70-$ \\
& services, personal services, education, health & $71,72-74,55,90$, \\
& $92-97,80-85$ \\
\hline Source: French Statistical Office (INSEE), French Nomenclature Level 60. \\
Note: Agriculture, forestry and fishing activities (01-05), financial activities (65-67), public \\
administration and associative activities (75, 91-99) were excluded, because they operate with \\
a different mode of financing.
\end{tabular}

